\title{
Bronchial obstruction and exhaled nitric oxide response during exercise in cold air
}

\author{
A. Therminarias, M.F. Oddou, A. Favre-Juvin, P. Flore, M. Delaire
}

Bronchial obstruction and exhaled nitric oxide response during exercise in cold air. A. Therminarias, M.F. Oddou, A. Favre-Juvin, P. Flore, M. Delaire. CERS Journals Ltd 1998. ABSTRACT: This study examines whether exhausting exercise in cold air induces bronchial obstruction and changes in exhaled [NO] and in exhaled NO output $\left(V^{\prime} \mathrm{NO}\right)$.

Thus, eight well-trained males performed two incremental exercise tests until exhaustion, followed by $5 \mathrm{~min}$ of recovery in temperate $\left(22^{\circ} \mathrm{C}\right)$ and cold $\left(-10^{\circ} \mathrm{C}\right)$ environments, at random. $\mathrm{At}-10^{\circ} \mathrm{C}$, they were dressed in warm clothes. Ventilation $\left(V^{\prime} \mathrm{E}\right)$, oxygen consumption $\left(V^{\prime} \mathrm{O}_{2}\right)$, carbon dioxide production, cardiac frequency $(f \mathrm{c})$, and [NO] and $V^{\prime}$ NO were measured continuously. Before and after each test, the subjects' maximal expiratory flow-volume curves and peak expiratory flow, forced expiratory volume in one second (FEV1) and forced expiratory flow at 25 (FEF25), 50 (FEF50) and $75 \%$ (FEF75) of forced vital capacity were determined.

At $-10^{\circ} \mathrm{C}$, significant decreases in FEV1 and FEF75 were observed after exercise. At rest and at the same submaximal intensity, $V^{\prime} \mathrm{O}_{2}, V^{\prime} \mathrm{E}$ and $f \mathrm{C}$ did not differ significantly. At rest and up to approximately $50 \%$ peak $V^{\prime} \mathrm{O}_{2},[\mathrm{NO}]$ and $V^{\prime} \mathrm{NO}$ values were lower at $-10^{\circ} \mathrm{C}$ than at $22^{\circ} \mathrm{C}$. Thereafter, and during recovery, the $V^{\prime} \mathrm{NO}$ response became similar at both -10 and $22^{\circ} \mathrm{C}$.

This study confirms that considerable hyperpnoea in cold air causes a detectable airway obstruction. This airway cooling also induces an initial decrease in the exhaled NO response. Since endogenous NO-production is involved in bronchial dilation, it cannot be excluded that this lack of production may favour the appearance of airway obstruction.

Eur Respir J 1998; 12: 1040-1045.
Laboratoire de Physiologie et Service de Médecine du Sport, Faculté de Médecine de Grenoble, Université Joseph Fourier, and Techniques de l'Imagerie, Modélisation et Cognitation-PRETA, Centre National de la Recherche Scientifique, Unité de Médecine et de Recherche, La Tronche, France.

Correspondence: A. Therminarias

Faculté de Médecine de Grenoble

Laboratoire de Physiologie

38700 La Tronche

France

Fax: 33476637186

Keywords: Airway cooling

airway obstruction

exercise

exhaled nitric oxide

Received: January 301998

Accepted after revision May 151998

This research was supported by a grant from the Programme thématique régional Rhône-Alpes
Muscular exercise in a cold environment requires both the warming and the humidification of large amounts of inspired air, resulting in a loss of heat and water from the respiratory tract. While these losses are known to induce airway obstruction in subjects with bronchial hyperresponsiveness, their effects are not well defined in normal nonatopic subjects. According to some authors, normal subjects do not develop measurable obstruction in response to airway cooling [1-3], whereas other authors claim that they respond by developing measurable obstruction when the stimulus is sufficiently great $[4,5]$. Under these conditions, the origin and mechanisms involved in the development of bronchial obstruction are still under debate [6-8].

Endogenous NO is produced in the lung by a family of NO synthases [9-11]. This NO is thought to be an important modulator of vascular tone and airway function in normal airways. Therefore, NO may be involved in several physiological mechanisms during airway cooling. Thus, in normal pulmonary circulation, NO mediates the vasodilation response to physical and chemical factors [9]. Moreover, NO mediates the nonadrenergic, noncholinergic neural inhibitory responses which represent the only neural bronchodilator mechanism in human airways [12, 13]. In addition, NO may contribute to acute inflammation and host defence in the lung [14].

NO may be detected in the air exhaled by humans and the amount of $\mathrm{NO}$ exhaled over time ( $\left.V^{\prime} \mathrm{NO}\right)$ may be meas- ured accurately and continuously [15-18]. Although the NO detected at the mouth is the difference between what is produced in the respiratory system and what is transformed or eliminated continuously by other endogenous pathways, $V$ 'NO is generally assumed to reflect the NO produced by cells within the respiratory tract. Therefore, if endogenous NO-production takes a part in the mechanisms involved during airway cooling, a change in exhaled [NO] may be expected during inhalation of cold air. The aim of the present study was: 1) to confirm that extensive airway cooling can induce detectable airway obstruction in nonatopic subjects, 2) to determine whether this cooling induces changes in the $V^{\prime}$ NO response, and 3) to determine whether a relationship may be established between both of these observations.

\section{Methods}

\section{Subjects}

Eight well-trained male subjects, engaged in various endurance activities (cross-country skiing, triathlon or running) for $>8 \mathrm{~h} \cdot$ week $^{-1}$, were studied. These subjects were selected because they were able to produce a high ventilatory response during exercise and, would therefore, need to warm up a large amount of air when they exercised in 
cold air. Their characteristics were as follows: mean age $31 \pm 2$ yrs; mean height $182 \pm 2 \mathrm{~cm}$ and mean weight $75.8 \pm$ $3.5 \mathrm{~kg}$. None of the subjects was a smoker, or had any present or prior history of respiratory disease, including rhinitis. The experiments were approved by the local human ethics committee, and all subjects gave their informed consent for their participation in this study.

On the first visit to the laboratory, all subjects underwent electrocardiographic (ECG) and basic spirometric examinations in order to ensure that the basic spirometric values were normal. Then, a preliminary maximal exercise test was performed on a cycle ergometer to familiarize each subject with the equipment and protocol.

\section{Experimental procedure}

Each subject returned to the laboratory between 7 and 15 days after completing the pretest. All subjects were asked to avoid any physical activity the day before each test. Tests were performed in a climatic chamber in which the temperature and the air velocity were monitored. Each participant performed two exercise tests, at random, at a temperate ambient temperature $\left(22 \pm 1^{\circ} \mathrm{C}\right)$ and at a cold ambient temperature $\left(-10 \pm 1^{\circ} \mathrm{C}\right)$. The air velocity was $10 \mathrm{~m} \cdot \mathrm{s}^{-1}$ during both tests. In the warm environment, subjects were dressed in shorts, shirts and sport shoes. At $-10^{\circ} \mathrm{C}$, they were dressed in warm trousers, anoraks, caps, gloves and sport shoes. The two tests were carried out 1 week apart. Before each test, subjects were weighed naked, and electrodes were placed on their chests to measure cardiac frequency $(f \mathrm{C})$. Then, three maximal expiratory flow-volume curves (MEFV) were carried out at three-minute intervals, using a spirometer (Brainware, Toulon, France) that was calibrated before each study using a three-litre syringe (Hans Rudolph, Kansas City, USA). The peak expiratory flow, forced expiratory volume in one second (FEV1), and forced expiratory flow at 25 (FEF25), 50 (FEF50) and 75\% (FEF75) of forced vital capacity were determined from the best value of each of the three manoeuvres. FEF75 and FEF25 are the expiratory flows when 75 and $25 \%$ of exhaled volume remains in the lung, respectively. Then, the subjects entered the climatic chamber, sat on a stationary bicycle (Monark, Varberg, Sweden) and began to breath into a mouthpiece attached to a unidirectional T valve. Their nostrils were obstructed with nose clips. Five minutes later, resting measurements were started, and control values were recorded for $5 \mathrm{~min}$. Following this, the subjects began to pedal. The exercise intensity was increased by 30 W every 3 min until the subjects were unable to continue, even with encouragement. During the test, ECG and tidal volume, respiratory rate, respiratory exchange ratio, oxygen consumption $\left(V^{\prime} \mathrm{O}_{2}\right)$ and carbon dioxide production $\left(V^{\prime} \mathrm{CO}_{2}\right)$ were determined continuously with the standard open-circuit method, using an automated computerized analysis system (Brainware). Expiratory flow ( $\left.V^{\prime} E\right)$ was measured with a pneumotachograph (Hans Rudolph) connected to the expiratory part of the unidirectional valve and a differential pressure transducer. Before each test, the zirconium oxide $\mathrm{O}_{2}$ cell (Servomex, Crowborough, UK) and infrared $\mathrm{CO}_{2}$ analysers (Servomex) were calibrated by using gases of known concentrations. Calibration of the pneumotachograph was carried out using the three-litre syringe. At the end of the exercise, a capillary blood sample was taken for measurement of plasma lactate concentration. The subjects were considered to have reached their peak $V^{\prime} \mathrm{O}_{2}\left(V^{\prime} \mathrm{O}_{2}\right.$,peak $)$ when three of the four following criteria were met: 1) no further increase in $V^{\prime} \mathrm{O}_{2}$ with increasing work load, 2) respiratory exchange ratio $>1,3) f_{\mathrm{C}}>90 \%$ of the maximum predicted value, and 4) plasma lactate value $>9 \mathrm{mM}$. For the last step, if the subject could not complete the three-minute period, the value was considered to be representative if this last step was maintained for $>1 \mathrm{~min}$. The value of $V^{\prime} \mathrm{O}_{2}$ determined during this step was considered as the $V^{\prime} \mathrm{O}_{2}$,peak. At the end of the test, the subjects continued to pedal for $2 \mathrm{~min}$ at $50 \%$ of the power reached at exhaustion, and then rested for 3 min while sitting on the bicycle. After this, the subjects left the climatic chamber and again carried out three MEFV measurements within $5 \mathrm{~min}$, at $22^{\circ} \mathrm{C}$. Then, the subjects sat on a chair and breathed into the T-valve again, and resting measurements were again performed for $10 \mathrm{~min}$ at $22^{\circ} \mathrm{C}$.

Inspired air. The circuit used in the present study has been described previously [15]. Because ambient air contains a variable [NO], throughout the experiments, all subjects breathed synthetic air free of NO, delivered through a Teflon tube from a pressurized gas cylinder containing $21 \%$ $\mathrm{O}_{2}$ balanced in $79 \%$ nitrogen (certified, Air Liquide, Lyon, France). Because Teflon and polyethylene are materials that do not generate or bind NO, the purified air mixture was held $1 \mathrm{~h}$ beforehand in a 2,000-L-capacity polyethylene bag hanging inside the climatic chamber. The bag was connected via a polyethylene tube to the inspiratory side of the Tvalve. The internal surface of the T-valve was coated with Teflon. The stability of these materials was checked beforehand, to ensure that the circuit did not interfere with NO measurement. This stability was found to last for $>24$ h. The $[\mathrm{NO}]$ and $\left[\mathrm{O}_{2}\right]$ in the bag were checked just before the experiment to ensure that the inspired [NO] was $<3$ parts per billion (ppb) and that the $\left[\mathrm{O}_{2}\right]$ was exactly $21 \%$.

Expired air. The expiratory part of the circuit was connected to the standard open circuit used and to the NO analyser set up outside the climatic chamber. During exposure at $-10^{\circ} \mathrm{C}$, the expiratory part of the circuit, which was inside the climatic chamber $(50 \mathrm{~cm})$, was protected with insulating material. Tidal volume, respiratory rate, respiratory exchange ratio, $V^{\prime} \mathrm{O}_{2}$ and $V^{\prime} \mathrm{CO}_{2}$ were determined continuously, and their values calculated by averaging the samples every $30 \mathrm{~s}$. All measurements were corrected for ambient temperature, barometric pressure and water vapour, and expressed BTPS units for $V^{\prime} \mathrm{E}$ and in the volume of gas at standard temperature and pressure that contains no water vapour units (STPD) for $V^{\prime} \mathrm{O}_{2}$ and $V^{\prime} \mathrm{CO}_{2}$. The $V^{\prime} \mathrm{O}_{2}$ value measured during the last step was considered to be $V^{\prime} \mathrm{O}_{2}$,peak.

For NO analysis, samples of exhaled air were drawn continuously from the expiratory part of the T-valve, at a flow rate of $400 \mathrm{~mL} \cdot \mathrm{min}^{-1}$. Water vapour was removed upstream from the analyser, by warming the sample. The [NO] was measured using a NO chemiluminescence analyser (model Topaze 2020, Cosma, Igny, France). The detection limit for [NO] was $1 \mathrm{ppb}$. Calibration was carried out before each experiment using a gas mixture of $883 \mathrm{ppb}$ NO (certified calibration, Air Liquide). Moreover, the linearity of the measurement system for low concentrations was checked weekly, using 50 and then $100 \mathrm{~mL}$ of the same certified 
calibration NO gas, injected into a Teflon bag filled with 3 $\mathrm{L}$ nitrogen, using the three-litre calibration syringe. For calibration, only Teflon-coated tubes were used. The NO signal, which became stable after $10 \mathrm{~s}$, was recorded continuously throughout the test, using a MacLab data-acquisition system, and was calculated by averaging the samples every $30 \mathrm{~s}$. The [NO] was expressed in ppb. The $V^{\prime}$ NO output molar rate was calculated by multiplying [NO] and $V^{\prime} \mathrm{E}$, after correcting for atmospheric pressure and temperature.

\section{Statistical analysis}

All data are expressed as means \pm SEM. The variations in [NO] and $V^{\prime} \mathrm{NO}$ were analysed by a repeated-measurement two-way analysis of variance (ANOVA), the two factors being the exercise intensity and the ambient temperature. When the ANOVA variance ratio $(\mathrm{F})$ value was significant, the student's t-test for paired observations was used to determine whether significant differences occurred between values obtained at rest and during exercise for each environment, and between values obtained at 22 and $-10^{\circ} \mathrm{C}$ at rest and for each exercise intensity. The accepted level of significance for all statistical tests was set at $5 \%$.

\section{Results}

The spirometric values obtained before and after exercise at $22^{\circ} \mathrm{C}$ and at $-10^{\circ} \mathrm{C}$ are given in table 1 . Control values are the mean of the two best values obtained before exercise. Slight but significant decreases in FEV1 (5\%) and FEF75 (10\%) were observed after exercise at $-10^{\circ} \mathrm{C}$ as compared to values obtained before exercise.

The total exercise duration was slightly shorter at $-10^{\circ} \mathrm{C}$ than at $22^{\circ} \mathrm{C}$ being $29 \pm 1 \mathrm{~min}$ and $30 \pm 1 \mathrm{~min}$, respectively $(\mathrm{p}<0.05)$. The greatest exercise intensity achieved by all subjects was $270 \mathrm{~W}$ and thus the parameters obtained at $22^{\circ} \mathrm{C}$ and at $-10^{\circ} \mathrm{C}$ were compared up to $270 \mathrm{~W}$. The mean values for $V^{\prime} \mathrm{O}_{2}$ (fig. 1a), $V^{\prime} \mathrm{CO}_{2}, V^{\prime} \mathrm{E}$, (fig. $1 \mathrm{~b}$ ), and $f \mathrm{C}$ (fig. 1c) were similar at rest and up to $270 \mathrm{~W}$ in both environments. At exhaustion, $V^{\prime} \mathrm{O}_{2}$,peak and the different parameters did not differ significantly in either environment, with the exception of $V^{\prime} \mathrm{E}$, which was slightly lower at -10 than at $22^{\circ} \mathrm{C}$ (table 2).

Table 1. - Pulmonary function before and after exercise at 22 and $-10^{\circ} \mathrm{C}$

\begin{tabular}{lrrc}
\hline & Before exercise & \multicolumn{2}{c}{ After exercise } \\
\cline { 3 - 4 } & & \multicolumn{1}{c}{$22^{\circ} \mathrm{C}$} & $-10^{\circ} \mathrm{C}$ \\
\hline FVC L & $6.87 \pm 0.40$ & $6.80 \pm 0.38$ & $6.48 \pm 0.34$ \\
PEF L $\mathrm{s}^{-1}$ & $12.92 \pm 0.59$ & $13.28 \pm 0.64$ & $12.39 \pm 0.53^{\#}$ \\
FEV1 L & $5.49 \pm 0.35$ & $5.58 \pm 0.90$ & $5.17 \pm 0.34^{* \#}$ \\
FEF75 L.s ${ }^{-1}$ & $9.68 \pm 0.73$ & $9.61 \pm 0.71$ & $8.76 \pm 0.71^{*}$ \\
FEF50 L $\cdot \mathrm{s}^{-1}$ & $6.27 \pm 0.60$ & $6.72 \pm 0.68$ & $5.64 \pm 0.49 \#$ \\
FEF25 L$\cdot \mathrm{s}^{-1}$ & $3.13 \pm 0.39$ & $3.23 \pm 0.39$ & $3.07 \pm 0.35$
\end{tabular}

FVC: forced vital capacity; PEF: peak expiratory flow; FEV1: forced expiratory volume in one second; FEF75, FEF50, FEF25: forced expiratory flow when 75,50 and $25 \%$ of the $\mathrm{FVC}$ remain in the lung respectively. $*: \mathrm{p}<0.05$ before exercise versus after exercise; \#: $\mathrm{p}<0.05$ : after exercise at $-10^{\circ} \mathrm{C}$ versus after exercise at $22^{\circ} \mathrm{C}$.
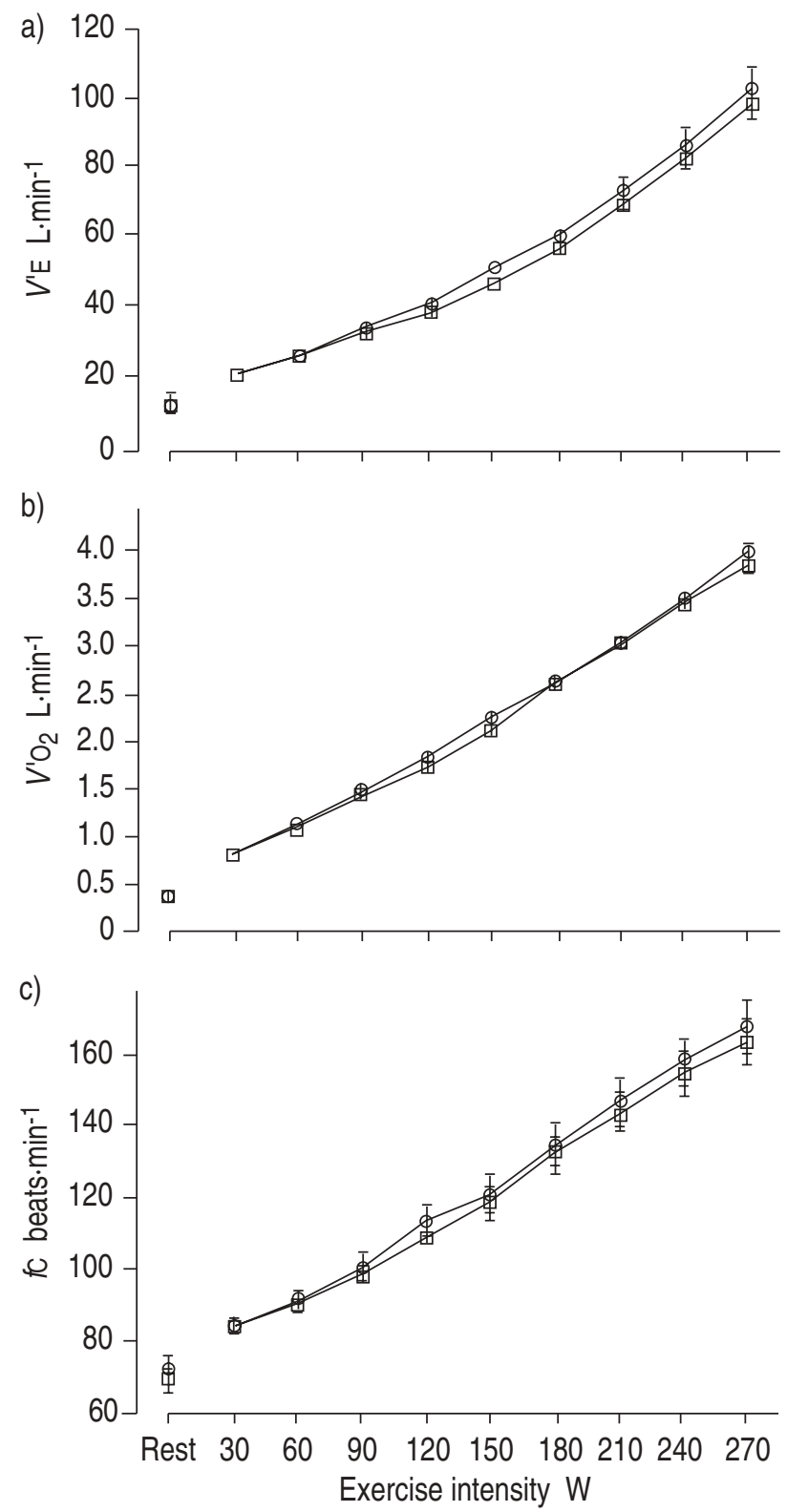

Fig. 1. - Mean values \pm SEM for a) ventilation $\left(V^{\prime} \mathrm{E}\right)$, b) oxygen consumption $\left(V^{\prime} \mathrm{O}_{2}\right)$ and $\left.\mathrm{c}\right)$ cardiac frequency $(f \mathrm{C})$ at rest and during submaximal exercise in eight trained males, at ambient temperatures of $22^{\circ} \mathrm{C}(\mathrm{O})$ and $-10^{\circ} \mathrm{C}(\square)$. No significant differences were observed at $-10^{\circ} \mathrm{C}$ versus $22^{\circ} \mathrm{C}$.

\section{Exhaled NO concentration}

Figure 2a illustrates the changes in [NO] values obtained at rest and during exercise, at 22 and $-10^{\circ} \mathrm{C}$. Compared with resting values, [NO] declined significantly in both environments with increasing exercise intensity. This decrease became significant at $>60 \mathrm{~W}$ at $22^{\circ} \mathrm{C}$ and at $>120$ $\mathrm{W}$ at $-10^{\circ} \mathrm{C}$. Moreover, the [NO] values measured at rest and at 30,90, 120 and $150 \mathrm{~W}$, were significantly lower at $-10^{\circ} \mathrm{C}$ than at $22^{\circ} \mathrm{C}$. The mean [NO] obtained at exhaustion (table 2 ), during the recovery and post-exercise did not differ significantly in either environment. 
Table 2. - Cardiorespiratory variables and [NO] and NO production ( $\left.V^{\prime} \mathrm{NO}\right)$ values at rest and at exhaustion

\begin{tabular}{|c|c|c|}
\hline & \multicolumn{2}{|c|}{ Temperature } \\
\hline & $22^{\circ} \mathrm{C}$ & $-10^{\circ} \mathrm{C}$ \\
\hline \multicolumn{3}{|l|}{ Rest } \\
\hline$V^{\prime} \mathrm{O}_{2} \mathrm{~L} \cdot \mathrm{min}^{-1}$ & $0.39 \pm 0.02$ & $0.39 \pm 0.10$ \\
\hline $\mathrm{RER}\left(V^{\prime} \mathrm{CO}_{2} / V^{\prime} \mathrm{O}_{2}\right)$ & $0.83 \pm 0.01$ & $0.87 \pm 0.02$ \\
\hline$V^{\prime} \mathrm{E} L \cdot \min ^{-1}$ & $12.5 \pm 1.18$ & $13.04 \pm 2.45$ \\
\hline$f \mathrm{C}$ beats $\cdot \mathrm{min}^{-1}$ & $72 \pm 4$ & $70 \pm 3$ \\
\hline \multicolumn{3}{|l|}{ Exhaustion } \\
\hline$V^{\prime} \mathrm{O}_{2}$,peak $\mathrm{L} \cdot \mathrm{min}^{-1}$ & $4.63 \pm 0.32$ & $4.49 \pm 0.32$ \\
\hline$V^{\prime} \mathrm{O}_{2}$,peak $\mathrm{mL} \cdot \mathrm{kg}^{-1} \cdot \mathrm{min}^{-1}$ & $61.59 \pm 4.2$ & $59.65 \pm 4.1$ \\
\hline $\operatorname{RER}\left(V^{\prime} \mathrm{CO}_{2} / V^{\prime} \mathrm{O}_{2}\right)$ & $1.02 \pm 0.01$ & $1.04 \pm 0.01$ \\
\hline$V^{\prime} \mathrm{E} \mathrm{L} \cdot \mathrm{min}^{-1}$ & $140.5 \pm 12.9$ & $129.7 \pm 13.8 *$ \\
\hline$f_{C}$ beats $\cdot \min ^{-1}$ & $186 \pm 3$ & $182 \pm 2$ \\
\hline Maximum power $\mathrm{W}$ & $322 \pm 22$ & $318 \pm 20$ \\
\hline [NO] ppb & $8.77 \pm 1.01$ & $9.99 \pm 1.95$ \\
\hline$V^{\prime} \mathrm{NO} \mathrm{nmol} \cdot \mathrm{min}^{-1}$ & $41.52 \pm 5.83$ & $44.99 \pm 11.11$ \\
\hline
\end{tabular}

$V^{\prime} \mathrm{O}_{2}$ : oxygen consumption; RER: respiratory exchange ratio; $V^{\prime} \mathrm{CO}_{2}$ : carbon dioxide production; $V^{\prime} \mathrm{E}$ : minute ventilation; $f \mathrm{C}$ : cardiac frequency; $V^{\prime} \mathrm{O}_{2}$,peak: peak $V^{\prime} \mathrm{O}_{2} ;$ ppb: parts per billion. *: $\mathrm{p}<0.05$ for $-10^{\circ} \mathrm{C}$ versus $22^{\circ} \mathrm{C}$.

\section{Exhaled NO output}

Figure $2 \mathrm{~b}$ illustrates the changes in $V^{\prime} \mathrm{NO}$ values obtained at rest and during exercise, at 22 and $-10^{\circ} \mathrm{C}$. At rest, $V^{\prime} \mathrm{NO}$ was significantly lower at $-10^{\circ} \mathrm{C}$ than at $22^{\circ} \mathrm{C}$. Compared to resting values, $V^{\prime} \mathrm{NO}$ increased significantly in both environments with increasing exercise intensity. This in-
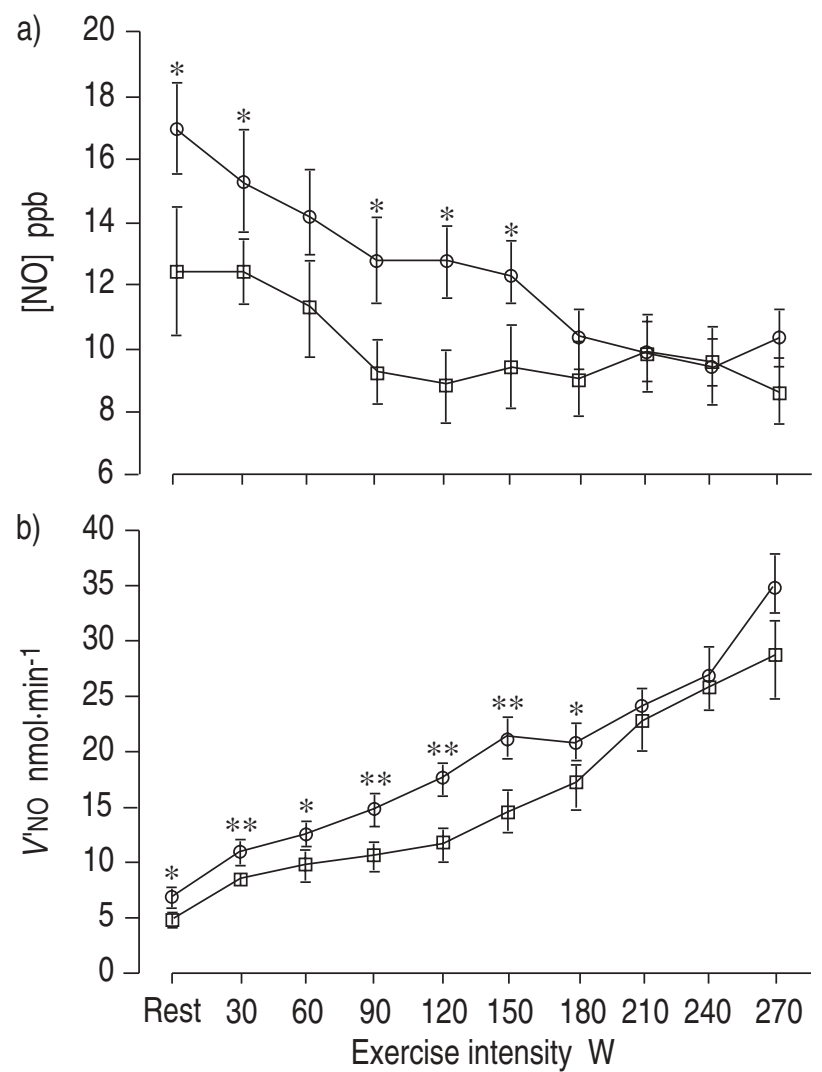

Fig. 2. - Mean values \pm SEM for a) $[\mathrm{NO}]$ and b) expired NO output $\left(V^{\prime} \mathrm{NO}\right)$ at rest and during submaximal exercise in eight trained males, at ambient temperatures of $22^{\circ} \mathrm{C}(O)$ and $-10^{\circ} \mathrm{C}(\square)$. ppb: parts per billion. *: $\mathrm{p}<0.05$; **: $\mathrm{p}<0.01$ for $-10^{\circ} \mathrm{C}$ versus $22^{\circ} \mathrm{C}$. crease became significant at $>30 \mathrm{~W}$ in both environments. $V^{\prime} \mathrm{NO}$ was significantly lower at $-10^{\circ} \mathrm{C}$ than at $22^{\circ} \mathrm{C}$ at $ð 180$ $\mathrm{W}$. The mean $V^{\prime}$ NO value obtained at exhaustion (table 2), during recovery and postexercise did not differ significantly in either environment

\section{Discussion}

We have observed that well-trained athletes performing incremental exhausting muscular exercise at $-10^{\circ} \mathrm{C}$ develop a measurable bronchial obstruction. They exhale less $\mathrm{NO}$ at -10 than at $22^{\circ} \mathrm{C}$, at rest and up to approximately $50 \% V^{\prime} \mathrm{O}_{2}$,peak. Thereafter, and during recovery, the $V^{\prime} \mathrm{NO}$ response becomes similar at -10 and $22^{\circ} \mathrm{C}$. Moreover, 15 min after exercise, they exhale the same amount of NO, at a temperate ambient temperature, whether exercise is performed at -10 or at $22^{\circ} \mathrm{C}$. These data show that, in addition to airway obstruction, airway cooling induces a decrease in the NO response. This decrease does not persist when the cold stimulus becomes too long or too severe. The functional meaning and possible consequences of this decrease remain to be explained.

The presence of bronchial obstruction observed after exercise at $-10^{\circ} \mathrm{C}$ was assessed according to whether or not there were a significant decrease in FEV1 and FEF75 which are assumed to indicate an obstruction in the upper part of the respiratory tract. This decrease is the consequence of a severe cold stimulus, since exposure to $-10^{\circ} \mathrm{C}$ lasted more than $30 \mathrm{~min}$ and hyperventilation reached values up to 130 $\mathrm{L} \cdot \mathrm{min}^{-1}$. These results are in agreement with previous experiments in which nonatopic subjects responded to extensive airway cooling by developing airway obstruction $[4,5]$. Airway cooling has been proposed as the key stimulus initiating events that lead to a bronchospasm [6] acting on thermosensitive receptors, and a parasympathetic reflex response, or directly on smooth muscle. However, according to other authors, evaporative water loss and changes in osmotic environment lead to bronchospasm. They hypothesize that changes in airway tonicity may trigger mediator-release from osmosensitive cells causing inflammation and smooth-muscle constriction [8].

During exercise, [NO] decreased and $V^{\prime} \mathrm{NO}$ increased at both -10 and at $22^{\circ} \mathrm{C}$. The mechanism that causes a rise in $V$ 'NO during exercise is not clear. The close relationship observed between $V^{\prime} \mathrm{NO}$ and variables related to metabolism magnitude strongly suggests that the origin of exhaled NO is linked to structures that are dependent on functions that become involved progressively as metabolism increases [15, 17, 18]. Thus, both haemodynamic alteration and hyperventilation have been suggested as being important stimuli for NO-production during exercise $[15,18,19]$. Moreover, it has been suggested recently that exercise does not necessarily increase $V^{\prime}$ NO but only shifts the elimination of a proportion of the $V^{\prime}$ NO from the blood to the airways, less NO diffusing into the blood and more being removed by ventilation [20]. In our study, the identical $V^{\prime} \mathrm{O}_{2}$ values measured at -10 and $22^{\circ} \mathrm{C}$ at rest and during exercise shows an identical metabolic involvement. In addition, the similar $V^{\prime} \mathrm{E}$ and $f \mathrm{C}$ values obtained at rest and at $\partial 270 \mathrm{~W}$ suggest similar ventilatory and haemodynamic alterations. It appears that no thermoregulatory mechanisms other than those involved in airway cooling were triggered. Consequently, the decrease in $V^{\prime}$ NO observed at 
$-10^{\circ} \mathrm{C}$ as compared with that at $22^{\circ} \mathrm{C}$ may be reasonably considered to be related to the effect of airway cooling. Since $V^{\prime}$ NO is generally assumed to reflect the NO produced by cells within the respiratory tract it may be assumed that the decrease in $V^{\prime}$ NO response is related to physiological or pathophysiological mechanisms that may be involved in the bronchial obstruction observed after airway cooling. During inspiration of cold air, heat is transferred from the walls of the tracheobronchial airways to the air by conduction and convection. In addition, water evaporates from the airway lining fluid to saturate the air. According to some authors, the epithelium is provided with both heat and water by increased flow and vasodilation [7]. This vasodilation is thought to be a possible factor in bronchial obstruction, since it may induce a decrease in bronchial diameter. NO-release has been shown to mediate the vasodilation response to physical and chemical factors in vascular smooth muscles [9]. If this vasodilation occurs, the decreased $V^{\prime}$ NO response observed in our study does not support the hypothesis of vasodilation mediated by NO. According to other authors, vasoconstriction rather than vasodilation, occurs in the bronchial vascular bed during cooling of the airway, as in the skin vascular bed [6]. This hypothesis was recently supported by LE MERRE et al. [21], who observed that the breathing of cold dry air may cause vasoconstriction in human central airways. Such an effect may imply reduced release and/or activity of the endogenous NO. It may explain the decrease in $V^{\prime} \mathrm{NO}$ observed in this study, from the onset of exercise. In fact, the occurrence of a biphasic response to increasing levels of thermal stress has been suggested by Le MERRE et al. [21], cold-air breathing causing an initial vasoconstriction followed by vasodilation as the thermal stress is prolonged. The biphasic $V^{\prime} \mathrm{NO}$ response observed at $-10^{\circ} \mathrm{C}$ in our study is consistent with such a hypothesis. However, it has been suggested that the bronchial obstruction observed after cooling may result from excessive bronchial vasodilation resulting from rapid airway warming [22]. If such a phenomenon does occur, this vasodilation does not find expression in an increase in the $V^{\prime} \mathrm{NO}$ response, since $15 \mathrm{~min}$ after exercise at $-10^{\circ} \mathrm{C}$, the $V^{\prime} \mathrm{NO}$ response is similar to that measured before exercise.

There is evidence that the NO delivered through bronchial circulation relaxes proximal airways [11]. In addition, NO is thought to be the principal mediator of neural bronchodilator (inhibitory nonadrenergic noncholinergic) response in the airways $[9,12,13]$. It has been observed recently that an infusion of a competitive inhibitor of NO synthase reduces the expired [NO] and results in an enhanced bronchoconstrictor response to acute allergic bronchial constriction [23]. Consequently, it cannot be excluded that the impaired NO-production observed at $-10^{\circ} \mathrm{C}$ may have contributed to the development of a bronchial constriction due to airway cooling.

In addition to its effects on vasodilation and bronchial dilation, NO is involved in the host-defence reaction [14, 11]. In the upper respiratory tract, NO appears to be important in maintaining ciliary function [24]. Moreover, it may have a role in sterilizing the mucosa, reducing the susceptibility to respiratory-tract infection $[14,25]$. Some reports have suggested that airway cooling causes increased vulnerability to upper respiratory infections [26]. A decrease in NO-production in the lung might play a role in this increased vulnerability to infection.
In conclusion, this study confirms that hyperventilation in a cold environment can cause airway obstruction provided that the stimulus is sufficiently great. Moreover, airway cooling induces first a decrease in the exhaled NO response, followed by a normalization in exhaled [NO] output values. This response may be involved in the effect of cold air on the vasomotor tone of the bronchial musculature. However, since decreased endogenous NO production may favour the appearance of bronchial constriction, it cannot be excluded that this impairment may favour the occurrence of airway obstruction during airway cooling.

\section{References}

1. Chapman KR, Allen LJ, Romet TT. Pulmonary function in normal subjects following exercise at cold ambient temperatures. Eur J Appl Physiol 1990; 60: 228-232.

2. Deal EC Jr, McFadden ER Jr, Hingram RH Jr, Breslin FJ, Jaeger JJ. Airway responsiveness to cold air and hyperpnea in normal subjects and in those with hay fever and asthma. Am Rev Respir Dis 1980; 121: 621-628.

3. Pekkarinen $\mathrm{H}$, Tukiainen $\mathrm{H}$, Litmanen $\mathrm{H}$, Huttunen $\mathrm{J}$, Karstu T, Länsimies E. Effect of submaximal exercise at low temperatures on pulmonary function in healthy young men. Eur J Appl Physiol 1989; 38: 821-825.

4. O'Cain CF, Dowling NB, Slutsky AS, et al. Airway effects of respiratory heat loss in normal subjects. J Appl Physiol 1980; 49: 875-880.

5. Paul DW, Bogaard JM, Hop WC. The bronchoconstrictor effect of strenuous exercise at low temperatures in normal athletes. Int J Sports Med 1993; 14: 433-436.

6. Deal EC Jr, McFadden ER Jr, Ingram RH Jr, Strauss RH, Jaeger JJ. Role of respiratory heat exchange in production of exercise-induced asthma. J Appl Physiol 1979; 46: 467-575.

7. Regnard J. Cold and the airways. Int J Sports Med 1992; 13: S182-S184.

8. Aitken ML, Marini JJ. Effect of heat delivery and extraction on airway conductance in normal and asthmatic subjects. Am Rev Respir Dis 1983; 131: 331-336.

9. Adnot S, Raffestin B, Eddahibi S. NO in the lung. Respir Physiol 1995; 101: 109-120.

10. Asano K, Chee C, Gaston B, et al. Constitutive and inducible nitric oxide synthase gene expression, regulation and activity in human lung epithelial cells. Proc Natl Acad Sci USA 1994; 91: 10089-10093.

11. Gaston B, Drazen JM, Loscalzo J, Stamler JS. The biology of nitrogen oxides in the airways. Am J Respir Crit Care Med 1994; 149: 538-551.

12. Belvisi MG, Stretton CD, Yacoub M, Barnes PJ. Nitric oxide is the endogenous neurotransmitter of bronchodilatator nerves in humans. Eur J Pharmacol 1992; 210: 221222.

13. Yu M, Wang Z, Robinson NE, Leblanc PH. Inhibitory nerve distribution and mediation of NANC relaxation by nitric oxide in horse airways. $J$ Appl Physiol 1994; 76: 339-344.

14. Barnes PJ. Nitric oxide and airway disease. Ann Intern Med 1995; 7: 27-91.

15. Chirpaz-Oddou MF, Favre-Juvin A, Flore P, et al. Nitric oxide response in exhaled air during an incremental exhaustive exercise. J Appl Physiol 1997; 82: 1311-1318.

16. Gustafsson LE, Leone AM, Persson MG, Wiklind NP, Moncada S. Endogenous nitric oxide is present in the exhaled air of rabbits, guinea pigs, and humans. Biochem Biophys Res Commun 1991; 181: 852-857. 
17. Iwamoto J, Pendergast DR, Susuki H, Krasney JA. Effect of graded exercise on nitric oxide in expired air in humans. Respir Physiol 1994; 97: 333-345.

18. Philips CR, Giraud GD, Holden WE. Exhaled nitric oxide during exercise, site of release and modulation by ventilation and blood flow. $J$ Appl Physiol 1996; 80: 1865-1871.

19. Massaro AP, Drazen JM. Invited editorial on "exaled nitric oxide during exercise: site of release and modulation by ventilation and blood flow". J Appl Physiol 1996; 80: 1863-1864.

20. Hyde RW, Geigel EJ, Olszowka AJ, et al. Determination of production of nitric oxide by lower airways of humans-theory. J Appl Physiol 1997; 82: 1290-1296.

21. Le Merre C, Kim HH, Chediak AD, Wanner A. Airway blood flow responses to temperature and humidity of inhaled air. Respir Physiol 1996; 105: 235-239.
22. Gilbert IA, Fonke JM, McFadden ER. Intra-airway thermodynamics during exercise and hyperventilation in asthmatics. J Appl Physiol 1988; 64: 2167-2174.

23. Mehta S, Craig ML, Rollenhagen JE, Haley KJ, Asano K, Drazen JM. Acute and chronic effects of allergic airway inflammation on pulmonary nitric oxide production. Am J Physiol 1997; 272: L124-L131.

24. Jain B, Rubinstein I, Robbins RA, Sisson JH. TNF-alpha and IL-1 beta upregulate nitric oxide-dependent ciliary motility in bovine airway epithelium. Am J Physiol 1995; 268: L911-L917

25. Croen KD. Evidence for an antiviral effect of nitric oxide. J Clin Invest 1993; 91: 2446-2452.

26. Shephard RJ. Metabolic adaptations to exercise in the cold. Sports Med 1993; 16: 266-289. 